\title{
Diyabetik Ayak Risk Faktörleri
}

\section{Özlem EKER', Doç. Dr. Selda ÇELIK²}

'Sağlık Bilimleri Üniversitesi Hamidiye Sağlık Bilimleri Enstitüsü İç Hastalıkları Hemşireliği Tezli Yüksek Lisans Öğrencisi, ISTANBUL

${ }^{2}$ Sağlık Bilimleri Üniversitesi Hamidiye Hemşirelik Fakültesi İç Hastalıkları Hemşireliği Anabilim Dalı, İTANBUL

\section{Derleme}

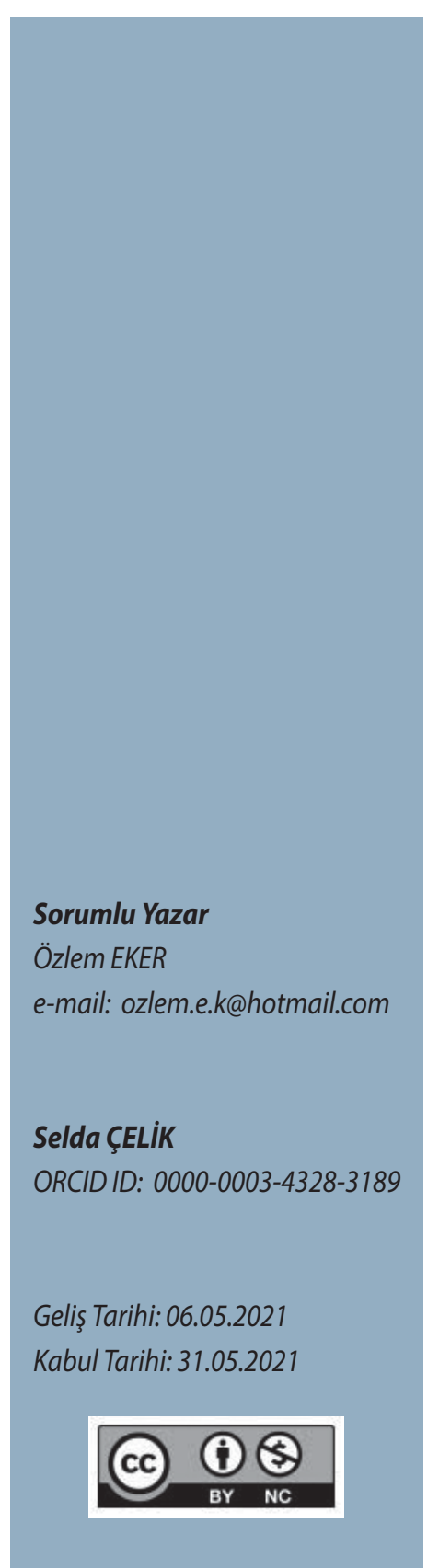

Özet

Diabetes mellitus, günümüzde en önemli sağlık sorunlarından biri olarak kabul edilmiş olan, sürekli tıbbi bakım gerektiren, yüksek sağlık maliyetlerine neden olan kronik metabolik bir hastalıktır. Diyabetin kısa veya uzun dönemde ortaya çıkan, çeşitli sistem, doku veya organ hasarlarına neden olan komplikasyonları mevcuttur. Mikrovasküler ve makrovasküler olarak sınıflandırılan bu komplikasyonlar, morbidite ve mortaliteyi artırmakla birlikte bireylerin yaşam kalitesini düşürmektedir. Mikrovasküler komplikasyonlardan biri olan diyabetik ayak ve diğer alt ekstemite komplikasyonları, tıbbi ve ekonomik tehdit oluşturan, dünya genelinde yaklaşık 40-60 milyon diyabetli bireyi etkileyen diyabetin sıklıkla görülen komplikasyonlarındandır. Diyabetik ayağın ortaya çıkmasına neden olan veya gelişmesini hızlandıran bazı risk faktörleri bulunmaktadır. Bu risk faktörlerinin farkındalığının arttırıması, diyabetik ayak riskine sahip hastaların erken dönemde belirlenmesi, risk sınıflandırmasının yapılması, hastanede kalıs süresini ve sağlık maliyetlerini azaltması, morbidite ve mortalite oranlarını düşürmesi açısından önemlidir. Bu derlemenin amacı, diyabetik nöropatiye bağlı olarak gelişen diyabetik ayağın risk faktörleri hakkında okuyucuya bilgi aktarmaktır.

Anahtar Kelimeler: Diyabet; Diyabetik ayak; Risk faktörleri

\section{Abstract}

\section{Risk Factors for Diabetic Foot}

Diabetes Mellitus, is a chronic metabolic disease that is considered one of the most important health problems of today, requires constant medical care and causes high health costs. Diabetes mellitus has complications that occur in the short or long term and cause various system, tissue or organ damage. These complications, classified as microvascular and macrovascular, increase morbidity and mortality, and decrease the quality of life. Diabetic foot and other lower extremity complications, one of the microvascular complications, are among the most common complications of diabetes that pose medical and economic threats and affect approximately 40-60 million people with diabetes worldwide. There are some risk factors that cause or accelerate the development of diabetic foot. It is important to increase the awareness of these risk factors, to identify patients with diabetic foot risk in the early period, to make risk classification, to reduce hospital stay and health costs, and to reduce morbidity and mortality rates. The aim of this review is to inform the reader about the risk factors of diabetic foot that develops due to diabetic neuropathy.

Keywords: Diabetes mellitus; Diabetic foot; Risk factors

\section{Giriş}

Diabetes Mellitus; pankreastan salınan insülin sekresyonunun yokluğu/eksikliği veya insülin etkisindeki defektler ya da insülin molekülündeki yapısal bozukluklar nedeniyle organizmanın protein, yağ ve karbonhidratlardan yeterince yararlanamadığı, akut metabolik ve kronik dejeneratif bozukluklara neden olan, glisemik kontrolün yanısıra sürekli tıbbi bakım gerektiren, hiperglisemi ile karakterize, kronik metabolik bir hastalıktır (Türkiye Diyabet Vakfı [TURKDIAB], 2020; American Diabetes Assosication[ADA], 2020], Sağlık Bakanlığı, 
2015, Türkiye Endokrinoloji ve Metabolizma Derneği [TEMD], 2020).

Diabetes Mellitus; günümüzde en önemli sağlık sorunlarından biri olarak kabul edilmiş olan, bulaşıcılığı olmasa dahi Dünya Sağlık Örgütü (DSÖ) tarafından görülme sıklığı hızla arttığı için salgın hastalık olarak kabul edilen önemli bir halk sağlığı sorunudur(Dünya Sağlık Örgütü[DSÖ], 2017; Coşansu, 2015; DSÖ, 2016). Ulusal Diyabet Federasyonu (IDF)'nun verilerine göre dünya genelinde 20-79 yaş arasındaki yetişkinlerde 2019 yılında 463 milyon olan diyabetli birey sayısının 2030'da 578 milyona, 2045 'te ise 700 milyona ulaşması, ülkemizde ise 20-79 yaş arasındaki yetişkinlerde 2019 yılında 6.59 milyon olan diyabetli birey sayısının 2030 yılında 8.35 milyona, 2045 yılında ise 10.36 milyona ulaşması tahmin edilmektedir (International Diabetes Federation [IDF], 2019).

Türkiye'de 2010 yılında yapılan, toplum temelli ikinci araştırma olan Türkiye, Diyabet, Hipertansiyon, Obezite ve Endokrinolojik HastaIıklar Prevelans Çalışması-II (TURDEP-II)'nın verilerine göre ise 1997-98 yılları arasında yapılan Türkiye, Diyabet, Hipertansiyon, Obezite ve Endokrinolojik Hastalıklar Prevelans Çalışması-I (TURDEP-I)'nın verileriyle karşılaştırıldığında 20 yaş ve üzeri erişkinlerde diyabet prevelansının 12 yılda \%90 artış göstererek \%13,7'ye ulaştığı ve 2010 yılında Türkiye'de 6.5 milyon diyabetli olduğu belirtilmiştir (Satman, 2012).

Diyabetli bireylerde plazma glukoz düzeylerinin kontrol altında tutulmadığı durumlarda kısa veya uzun dönemde çeşitli sistem, organ ya da doku hasarları ortaya çıkabilir. Diyabete bağlı olarak ortaya çıkan bu hasarlara "diyabet komplikasyonları" adı verilir. Diyabet komplikasyonları mortaliteyi, morbiditeyi ve sağlık maliyetlerini artırmakla beraber yaşam beklentisini ve kalitesini düşürür (Uludağ, 2010).

Diyabet komplikasyonları akut ve kronik olarak sınıflandırılır. Akut komplikasyonlar; diyabetik ketoasidoz, hiperglisemik hiperozmolar durum/hiperglisemik nonketotik koma, laktik asidoz ve hipoglisemidir (TEMD, 2020; Uludağ, 2010). Takip ve tedavideki tüm gelişmelere rağmen bu komplikasyonlar yaşamı tehdit edecek düzeylerde olabilir ve mortaliteyi artırabilir (Sağlık Bakanlığı, 2015; TEMD, 2020; Önmez, 2017). Hiperglisemi ve uzun vadede organ sistemlerine olan etkileri sebebiyle vücutta inflamatuvar süreçler tetiklenir ve sonuçta kronik komplikasyonlar ortaya çıkar (Özşenel, 2014). Bu kronik komplikasyonlar mikrovasküler (retinopati, nefropati ve nöropati) ve makrovasküler(koroner arter hastalığı, serebrovasküler hastalık ve periferik arter hastalığı) olmak üzere iki grupta incelenir (Börkü Uysal, 2019). Kronik komplikasyonlar yıllar boyunca semptom vermeden ilerleyebilir. Bu nedenle diyabetli bireyler, semptom olmasa dahi öneriler doğrultusunda düzenli olarak komplikasyonlar açısından tetkik ve muayenelerini yaptırmalıdır (Uludağ, 2010).

Bu derlemede diyabetin mikrovasküler komplikasyonlarından biri olan diyabetik nöropatiye bağlı olarak gelişen diyabetik ayak yaralarının risk faktörleri hakkında okuyucuya bilgi aktarılması amaçlanmıştır.

\section{Diyabetik Ayak}

Diyabetik ayak ülserleri, etkin bir ayak bakımı yapılmadığı ve koruyucu önlemler alınmadığı takdirde sık gelişen, diyabet hastalarının uzun süre hastanede kalmalarına ve yüksek oranda alt ekstremite ampütasyonlarına neden olan, multidisipliner yaklaşım gerektiren diyabetin en önemli komplikasyonlarından biridir (Akçay, 2012; Korkmaz, 2015;Toygar, 2020).

Diyabetik ayak ülserleri nöropatik, nöro-iskemik veya iskemik kökenli olabilir (TEMD, 2020). Uzun süren hiperglisemi, kontrolsüz kan glukoz düzeyi, özellikle ayaklardaki damar ve sinirlerin hasarına yol açar. Bu hasar sonucunda hastaların, ayaklarında ağı duyumunun azalmasına bağlı olarak yaralanmaların farkına varması zaman alır. Duyu azalmasına ek olarak ısıyı algılamada sorun yaşayan hastalar ayakları üşüdüğünde ısıtmak isterler ve fark etmeden ağır yanıklar ortaya çıkabilir (Uludağ, 2010). Perfüzyonu kötü olan dokularda tekrarlayan travmalar sonrası iskemik ülserlerin gelişme riski artar (Demir, 2007). Ayrıca nöropatinin sonuçlarından biri de ter ve yağ bezlerinde disfonksiyondur. Ayakta normal terleme ve ısı regülasyonunun bozulması sonucunda ayak plantar yüzeyinde anhidroz, hiperkeratoz, kuruma ve soyulma gibi semptomlar meydana gelir (Demir, 2004; Ekim, 2016). Bunların sonucunda deride çatlaklar oluşur ve buradan mikroorganizmaların girişi enfeksiyona neden olur. Enfeksiyonu takiben osteomyelit, mikroemboli gibi diğer komplikasyonlar gelişir (Demir, 2004). Nöropatiye bağlı olarak hastalar yaralanmaların, travmaların, yanıkların, fissürlerin farkına varmakta gecikebilirler ve bu gecikme nedeniyle erken koruyucu ve tedavi edici girişimlerin uygulanamaması diyabetik ayak ve yara gelişimini hızlandırır (Uludağ, 2010; Demir, 2004). Damarların harabiyeti nedeniyle kan akımının azalması sonucunda ayakta oluşan her türlü yaranın iyileşmesi çok uzun sürebilir ya da hiç iyileşmeyen yaralar ortaya çıkabilir (Uludağ, 2010). Doku perfüzyonu sağlanmadan iskemik ülserlerin tedavi edilmesi mümkün değildir (Demir, 2007).

\section{Diyabetik Ayak Epidemiyolojisi}

Diyabetik ayak, diyabetik hastalarda sık görülen, büyük bir tıbbi ve ekonomik tehdit oluşturan, morbidite ve mortalitenin önemli ölçüde artmasına sebep olan diyabetin en önemli, yıkıcı ve ciddi komplikasyonlarından biridir (Iraj, 2013; Al-Rubeaan, 2015; Naicker, 2009). Diyabetik hastaların yaklaşık \%20-40'ı diyabetik nöropatiden muzdariptir; bunun neredeyse \%50'si genellikle tanıdan sonraki yirmi yıl içinde semptomatik periferik vasküler hastalık geliştirir (Sunny, 2019). Diyabetik ayak ve alt ekstremite komplikasyonları, dünya genelinde yaklaşık 40-60 milyon diyabetli bireyi etkilemekle beraber önemli bir morbidite kaynağı olarak belirtilmiştir (IDF, 2019).

Diyabetik ayak, yaşam kalitesinde azalmanın yanısıra, hastanede yatış sürelerinin uzamasına, tedavi maliyetlerinin artmasına ve alt ekstremite ampütasyonlarının oranının artmasına neden olmaktadır (Akçay, 2012). Diyabetik ayak ülseri olan kişilerin, olmayanlara göre beş kat daha fazla sağlık harcaması yaptığı belirtilmiş̧tir (IDF, 2019).

Diyabetik ayak ülseri, yaranın enfeksiyonla karşılaşması ya da osteomiyelit durumunda ampütasyona varan sonuçlara neden olabilir (Amin, 2016). Diyabeti olmayanlarla karşılaştııılığında diyabetik hastaların ampütasyon riski 10 kat daha fazladır ve uzun vadede prognoz- 
ları kötüdür (Kastenbauer, 2003). Dünyada, diyabetin bir sonucu olarak her 30 saniyede bir alt ekstremitenin veya bir alt ekstremitenin bir kısmının amputasyona uğradığı tahmin edilmektedir (Amoah, 2018; IDF, International Working Group, 2005). Amputasyon oranını düşürmek için, diyabetik ayağa yol açan risk faktörlerini belirlemek ve önlem almak gerekir (Lauterbach, 2010).

Diyabetik ayak, sadece bir hasta sorunu değil, aynı zamanda dünya çapında önemli bir sağlık bakım sorunudur. Bu sorunun risk faktörlerinin belirlenmesi, sağlık çalışanlarının daha iyi önleme programları oluşturmalarını sağlayacaktır (Al-Rubeaan, 2015). Ulusal Diyabet Federasyonu'na göre bunun için, sağlık çalışanlarının diyabetik ayak komplikasyonlarının yönetimi konusunda farkındalığının ve bilgisinin artırıması ve ülser riskine sahip ayaklar için düzenli tarama ve risk sınıflandırması yapmak olmak üzere iki yönetim stratejisine öncelik vermek gerekmektedir (IDF, 2019). Ayrıca hastaların diyabetik ayak ülseri konusunda eğitilmesi, bilgi, tutum ve uygulamaların önemli ölçüde geliştirilmesinde önemli rol oynar ve ayrıca hastanede kalış sürelerini kısaltabilir (Jan, 2016).

\section{Diyabetik Ayak Risk Faktörleri}

Diyabet hastalarında diyabetik ayak gelişmesinde ası neden motor, duyu ve otonomik sinir fonksiyonlarında diyabete bağlı gelişen hasarlardır (Ekim, 2016). Bu hasarlara ek olarak kontrolsüz kan glukoz düzeylerinden, hastaların ayak bakım ve/veya bilgi yetersizliğinden kaynaklanan bazı risk faktörleri hastalarda diyabetik ayak gelişmesine neden olabilir veya diyabetik ayak gelişmesi sürecini hızlandırabilir. Diyabetik ayak ülserlerinin gelişmesi için, genellikle iki veya daha fazla risk faktörünün beraber bulunması gerekir (Naicker, 2009). Diyabetik ayak için yaygın risk faktörleri tablo 1'de verilmiştir (Sunny, 2019; Amin, 2015; Ahmad, 2013).

Risk faktörlerine ek olarak diyabetik ayağın iyileşmesini olumsuz yönde etkileyen etmenler ise ileri yaş, ülserin boyutları (ne kadar büyük ve derinse o kadar kötü), kalp yetersizliği, yardımsız ayakta duramayan ya da yürüyemeyen hastalar, son evre böbrek yetersizliği olarak bildirilmiştir (Prompers, 2008).

Diyabetik ayak ülserlerini önleyici yaklaşımlardan ilki ve en önemlisi yüksek riskli hastaların tanımlanmasıdır (Hokkam, 2009). Bunun için öncelikle risk faktörleri belirlenir, sonrasında bir risk sınıflandırması yapılır. Uluslararası Diyabetik Ayak Çalışma Grubu, günlük klinik uygulamada kolaylıkla uygulanabilir olduğu kanıtlanmış bir risk kategorizasyon sistemi oluşturmuştur (IDF, International Working Group, 2005). Riskli hastaların tanımlanmasından sonra diyabetik ayak ülserlerinin önlenmesinde hasta eğitimi şarttır (Ahmad, 2016). Hastalara ayaklarına uygun olmayan ayakkabılardan, sigaradan, çıplak ayakla yürümekten ve yetersiz öz bakımdan kaçınmaları konusunda eğitim verilmelidir (Hokkam, 2009). Önleyici stratejiler, hem iyileştirilmiş hasta sonuçları hem de kısa ve uzun vadeli maliyet etkinliği için multidisipliner bir yaklaşım içermelidir (Ahmad, 2016). Hastaların risk faktörlerini bilmeleri ve bu risk faktörlerinden kaçınmaları etkili tedavilerin ve önleyici bakım önlemlerinin oluşturulmasına yardımcı olacaktır (Hokkam, 2009).

Periferik nöropati: Periferik nöropati, periferik sinir sistemindeki bir hasar sonucunda, bazı kalıtsal hastalıklar, çeşitli sistemik hastalıklar, enfeksiyon ve ilaçlardan kaynaklanan ve çeşitli formları olan yaygın bir nörolojik hastalıktır. Diyabetik periferik nöropati ise, diyabetli bireylerde, periferik nöropatiye neden olan diğer nedenlerin dışlanmasından sonra periferik sinir disfonksiyonunun belirtilerinin mevcut olmasıdır (Pop-Busui, 2017). Hastanın ayağında/ayaklarında, üşüme, özellikle geceleri artan yanma, sıcaklık ayrımını yapamama, karıncalanma, uyuşma, elektrik çarpması hissi, dokunma ve titreşim gibi duyusal uyaranlara karşı azalan duyarlııı, ayak parmaklarından başlayan ve proksimal olarak ilerleyen ağrılar gibi belirti ve bulgular görülebilir (Ahmad, 2016; Fiçioğlu, 1994). Aynı zamanda, yağ ve ter bezlerinin fonksiyon bozukluğu nedeniyle terleme ve ısı regülasyonu fonksiyonları bozulur ve bunun sonucunda kuruyan ciltte çatlaklar ve enfeksiyona yatkınlık meydana gelir (Ekim, M. 2016; Ahmad, 2016). Duyu kaybına bağlı olarak travmalar hissedilemez ve ülser gelişimine yatkınlık artar. Diyabet süresinin fazla olması, $\mathrm{HbA} 1$ c düzeyinin yüksek olması, sigara kullanımı ve erkek cinsiyet nöropatinin risk faktörleridir (Biberoğlu, 2003). Diyabetli bireylerde \%55-70 oranında periferik nöropati gelişebilir, bu oran diyabetik ayak ülseri olan hastalarda \%90'a kadar yükselebilir (Ekim, 2016). Günümüzde diyabetik nöropati için birtakım tedavi stratejileri olmakla birlikte etkili bir tedavi yoktur fakat diyabetli bireylerde nöropati oluşma riskini azaltmanın tek yolu glisemik kontrolü sağlamaktır (Said, 2007).

Periferik arter hastalığı: Diyabet, bireylerde periferik arter hastalığının görülme sıklığını diyabeti olmayan bireylere göre en az dört kat artırır, bu oran yaş ilerlemesi ve diyabet süresinin uzunluğu ile artar (Ahmad, 2016). Ulusal Sağlık ve Beslenme İnceleme Araştırması (NHANES)'nın verilerine göre, genel popülasyonda periferik arter hastalığı

Tablo 1: Diyabetik Ayak için Yaygın Risk Faktörleri

- $\quad$ Periferik nöropati

- Periferik arter hastalığı

- Enfeksiyon

- Diyabet süresi

- Diyabete bağlı diğer komplikasyonların varlığı

- Ayak deformiteleri ve ayağa uyumlu olmayan ayakkabılar giyilmesi

- Charcot ayağı

- Erkek cinsiyet

- Sigara kullanımı

- Hastaların ayak bakım yetersizliği

- Geçirilmiş ayak ülseri

- Kontrolsüz kan glukoz düzeyi/ Uzun süreli hiperglisemi

- Travma 
prevalansı \% 4,5 iken diyabetli bireylerde bu oran \%9,5 bulunmuştur (Ibrahim, 2017). Diyabete bağlı periferik arter hastalığı, ekstremitelerde küçük ve büyük damarları etkileyerek kan akımının azalmasına neden olur ve mevcut olan nöropatinin etkilerinin şiddetlenmesine neden olur (Ahmad, 2016). Ek olarak, periferik arter hastalığı ciltteki küçük açıklıkların iyileşmesini engeller ve büyümelerine ve enfeksiyona açık hale gelmelerine katkı sağlar (Börkü Uysal, 2019). Diyabetik ayağın ilerleyişini ve sonucunu belirleyen en önemli faktör periferik arter hastalığıdır. Perfüzyonu kötü olan dokularda travma sonrası iskemik ülserler gelişir. Doku perfüzyonu sağlanmadan iskemik ülserlerin tedavi edilmesi mümkün değildir (Demir, 2007). Akçay ve arkadaşlarının diyabetik ayak yarası olan 131 hasta dahil ettikleri çalışmalarında hastaların \%77'sinde periferik arter hastalığının komorbid hastalık olduğu saptanmıştır (Akçay, 2012). Schaper'in Avrupa Diyabet Çalışma Grubu ve Alt Ekstremite projesi kapsamında diyabetik ayak yarasına sahip 1232 hasta dahil ettiği araştırmasında hastaların yaklaşık \%50'sinde periferik arter hastalığı belirtilerinin olduğunu bulmuş ve periferik arter hastalığına sahip diyabetli hastaların ayak ülseri gelişimi açısından çok yüksek riskli hastalar olduğunu belirtmiş, önleme stratejilerinde bu hastalara daha fazla odaklanılmasını önermiştir (Schaper, 2012).

Enfeksiyon: Diyabetik ayaktaki aktif enfeksiyon, yükselen eritem, ödem, cerahat, artan drenaj ve kötü kokunun klasik belirtilerini içerir fakat diyabetik hastalar nöropati nedeniyle ülserasyonların ilerlemesini hissetmez ve yine nöropati nedeniyle enfeksiyonların belirti ve bulgularının (yani sıcaklık artışı, ağrı, hassasiyet) fark edilmesi zaman alır (Iraj, 2013; Ahmad, 2016). İlk enfeksiyon belirtisi, kan şekeri kontrolünün kaybı veya grip benzeri bir sendrom olabilir (Ahmad, 2016). Bu enfeksiyonlar genellikle polimikrobiyaldir ve aerobik gram pozitif koklar (Staphylococcus aureus), gram negatif basiller (Escherichia coli), Klebsiella türleri ve Proteus türleri) ve anaerobları (Bacteroides sp. ve Peptostreptococcus sp.) içerir (Ahmad, 2016). Diyabetik ayakla ilgili yapılmış bir çalışmada diyabetik ayağın en yaygın risk faktörlerinin nöropatinin yanında ayak enfeksiyonları olduğu bulunmuştur (Rajyalakshmi, 2017). Ahmad ve ark.'nın diyabetik ayak risk faktörlerini saptamak için yaptıkları ve diyabetik ayağa sahip 196 hastayı dahil ettikleri araştırmalarında hastaların \%85,7'sinde ayak enfeksiyonuna ve \%43,4'ünde Staphylococcus aureus enfeksiyonuna rastlanmıştır. Bu çalışmanın sonuçlarına paralel olarak Jan ve ark'nın 150 hasta dahil ettikleri araştırmalarında da hastaların \%74'ünde ayak enfeksiyonuna rastlanmıştır (Jan, 2016; Ahmad, 2013). Yapılan bu çalışmaların sonuçlarından yola çıkıldığında ayak enfeksiyonlarının diyabetik ayak gelişiminde önemli bir risk faktörü olduğu anlaşılmaktadır. Yara enfeksiyonları dışında ayakta bulunan mantar enfeksiyonları da diyabetik ayak gelişim riskini artıran faktörlerdendir. Mantar enfeksiyonları, ayak parmakları arasında kesiklere neden olur. Bu nedenle hastalar ayaklarını günlük olarak incelemeli ve mantar enfeksiyonuna dair belirtiler ya da kesikler gördüklerinde sağlık kuruluşuna başvurmalıdırlar. Diyabetik ayakta enfeksiyon, tedavisi zor ve yüksek maliyetli bir komplikasyondur. Hastaların genellikle uzun süreli ilaçlar almasına ve hastanede kalma süresinin uzamasına neden olur (Iraj, 2013).

Diyabet süresi: Diyabet süresi, diyabetik ayak için önlenemeyen risk faktörlerinden biridir. Diyabet süresi diyabetik ayak gelişimine doğrudan etki göstermekle birlikte dolaylı olarak da etkileri vardır. Periferik nöropati ve periferik arter hastalığının gelişmesinde diyabet süresi önemli bir risk faktörüdür ve bu şekilde diyabetik ayak gelişimine dolaylı olarak etki gösterir. Özkara ve arkadaşlarının diyabetik ayağa sahip 84 hastayla yaptıkları çalışmada hastaların \%69'unun; Ahmad'ın 196 diyabetik ayak hastası ile yaptığı çalışmada hastaların \%52'sinin 10 yıl ve daha uzun süredir diyabet hastası olmaları diyabetik ayağın gelişiminde diyabet süresinin önemini göstermektedir (Ahmad, 2013; Özkara, 2002).

Diyabete bağlı diğer makrovasküler komplikasyonların varlığı: Moss ve arkadaşları alt ekstremite ampütasyonları ile diyabetik retinopati arasındaki ilişkiyi inceledikleri çalışmalarında artan diyabetik retinopati şiddetinin alt ekstremite ampütasyonu insidansı ile ilişkili olduğunu; diyabetin retinadaki damarlarda fokal veya jeneralize daralmaya neden olduğunu ve özellikle jeneralize daralmanın alt ekstremite ampütasyonu riskini artırdığını bulmuşlardır (Moss, 2003). Korkmaz ve arkadaşlarının diyabetik ayak ülserine sahip 104 hasta ile yaptıkları çaIışmada, hastaların \%44.2'sinde diyabetik retinopati, \%16.3'ünde polinöropati ve \%11.5'inde nefropati varlığı saptanmıştır (Korkmaz, 2015). Araştırma sonuçları diyabete bağlı diğer komplikasyonların varlığının diyabetik ayak gelişiminde etkili olduğunun göstergesidir.

Ayak deformiteleri ve ayağa uyumlu olmayan ayakkabılar giyilmesi: Diyabetik ayak yaralarının açılmasında pençe parmak, basınç bölgelerinde oluşan nasırlar ve Charcot ayağı gibi ayak deformiteleri önemli faktörlerden biridir. Genellikle duyu kusuru olan nöropatik ayaklarda kemik çıkıntılar üzerinde meydana gelen mekanik baskılar sonucu cilt sorunları meydana gelir. Koruyucu duyunun olmadığı bir ayakta uygun olmayan ayakkabıların giyilmesi gibi mekanik baskıyı arttıran durumlar cilt ülserlerine neden olabilir. (Ayanoğlu, 2015). Abbot'un toplum temelli hasta kohort çalışmasında diyabetik ayak yaralarının ana nedeninin \%55 oranında ayakkabıdan gelen basınç olduğu tespit edilmiştir (Abbott, 2002). Ayak yaralarının büyük bölümü ayağa uygun ve rahat ayakkabı tercih etmekle önlenebilmektedir. Ayağa uygun ayakkabılar seçilmeli, ayağı sıkmayan deri veya bez ayakkabılar giyilmelidir. Hastalar mümkünse kendi ayak kalıpları alınarak üretilen ayakkabıları kullanmalıdır. Ayakkabı genişliği ayak genişliği kadar olmalı, ayağı tam kavramalıdır; önü sivri, yüksek topuklu, açık burunlu ayağı rahatsız edecek ayakkabılar tercih edilmemelidir (Hokkam, 2009).

Charcot ayağı: Diyabetik nöropatisi olan bazı hastalarda, nöropatiye bağlı olarak enfeksiyöz olmayan kemik ve eklem yıkımının söz konusu olduğu, ayaklarda ödem, eritem ve renk değişikliği ile karakterize nöro-osteoartropati olarak da bilinen 'Charcot ayağı' diyabetik ayağın en tahrip edici bileşenlerinden biri olarak kabul edilir (IDF, International Working Group 2005; Ahmad, 2016). Uzun süreli (>10 yıl) diyabeti olan hastada ayakta ani ortaya çıkan inflamasyon (şiş, sıcak, kızarık ayak), enfeksiyon dışlandığı anda Charcot ayağı olarak değerlendirilmelidir 
(IDF, International Working Group 2005). Nöropati nedeniyle ağrıyı hissetmemeleri gerekirken Charcot ayağa sahip hastalar, ağrıdan şikayetçidirler (Ibrahim, 2017). Charcot ayaktan şüphelenilen veya tanısı konmuş Charcot ayağı olan kişiler, etkilenen eklemleri sabitlenmek ve yara gelişmesi önlenmek üzere uzun süreli yükten kurtarma için hemen multidisipliner ayak bakımı ekibine sevk edilmelidir (Ahmad, 2016). Özkara ve arkadaşlarının yaptıkları araştırmada hastaların \%10,7'sinde, Korkmaz ve arkadaşlarının araştırmasında hastaların \%3.8'inde Charcot ayağı tespit edilmiştir (Özkara, 2002; Korkmaz, 2015).

Erkek cinsiyet: Erkeklerde eklem mobilitesi kadınlardan daha az olmakla birlikte ayak basıncı daha yüksek olduğundan ülser riski daha fazladır (Sözen, 2012). Özkara ve arkadaşlarının 84 diyabetik ayak hastasıyla yaptıkları çalışmada kadın/erkek oranının 0.75 olduğu ve erkek hasta sayısının daha fazla olduğu, Toygar ve arkadaşlarının diyabetik ayağa sahip 171 hasta dahil ettikleri çalışmalarında hastaların $\% 67,3$ 'ünün erkek olması erkek cinsiyetin diyabetik ayak ülseri gelişiminde önemli risk faktörlerinden biri olduğunun göstergesidir (Özkara, 2002; Toygar, 2020). Benzer şekilde Hokkam'ın diyabetik ayak risk faktörlerini araştırdığı ve incelediği çalışmasında erkek cinsiyet diyabetik ayağa sahip hasta grubunda anlamlı olarak daha yaygın bulunmuştur (Hokkam, 2009).

Sigara kullanımı: Sigara kullanımı, diyabetik ayak ülseri için bağımsız bir risk faktörüdür. Sigara içmek periferik vasküler hastalığa, dislipidemiye, iskemik kalp hastalıklarına ve iskemik ayağa yol açar (Jan, 2016). Al Rubbean ve arkadaşlarının bir retrospektif kohort çalışmasında sigara içenlerin yüzdesi diyabetik ayak ülseri ve kangren vakalarında anlamlı olarak daha yüksek bulunmuştur (Al-Rubeaan, 2015).

Hastaların ayak bakım yetersizliği: Literatürdeki çalışmalar incelendiğinde, düzenli ayak bakım davranışlarının diyabetik ayak gelişimini önlemede önemli olduğu vurgulanmıştır (Sözen, 2012; Güner, 2005). Hastaların ayak bakımına dair yapacağı birkaç uygulama diyabetik ayağı önlemek için önemlidir. Bunlar; ayağın günlük izlemi, kendi kendine ayak muayenesi, ayakları her gün yıkama, yıkamadan önce suyun ısısının kontrol edilmesi, yıkanan ayakların kurulanması, nemlendirilmesi, oluşmuş nasırlara uygun şekilde müdahale edilmesi, tırnak bakımı, üşüyen ayağa doğru müdahale, düzenli ayak-bacak egzersizlerinin yapılması, pamuklu ve bileği sıkmayan çorap tercih edilmesi, çıplak ayak ile dolaşmama gibi davranışlardır (Güner, 2005). Yapılan araştırmalarda diyabetik ayağa sahip hastaların olmayanlara göre ayak bakımı davranışlarını anlamlı derecede düşük uyguladığı bulunmuştur (Sözen, 2012; Güner, 2005).

Daha önce geçirilmiş ayak ülseri öyküsü: Geçirilmiş ayak ülserleri olan diyabetli hastalarda, diyabetik ayak ve ülser oluşma riski oldukça yüksektir. Özkara ve arkadaşlarının 84 diyabetik ayak hastasıyla yaptıkları çalışmada hastaların \%28,5'inde geçirilmiş ayak ülseri öyküsü mevcuttur (Özkara, 2002).

Kontrolsüz kan glukoz düzeyi: Diyabete uyumu zayıf olan, uzun süre hiperglisemik seyreden veya kontrolsüz kan glukoz düzeylerine sahip olan hastaların uzun süre iyileşmeyen veya ampütasyonla sonuç- lanan ayak ülserlerinin olduğu yapılan bazı çalışmalarda kanıtlanmıştır (Naicker, 2009; Ahmad, 2013). Naicker ve ark.'nın diyabetik ayak risk faktörlerini araştırdıkları çalışmalarında diyabetik ayağı olan hastaların kan glukozu kontrollerinin daha zayıf olduğunu saptamışlardır (Naicker, 2009).

Travma: Periferik duyusal nöropati hastaların farkında olmadan ayaklarına büyük veya tekrarlanan küçük travmalara maruz kalmasına neden olur (Börkü Uysal, 2019). Bu küçük travmalar, diyabetik ayak ülseri gelişmesinde ve kronikleşmesinde önemli bir risk faktörüdür. Hastaların kuru cilde sahip olması ve küçük travmalara maruz kalmalarının kombinasyonu sonucunda mikroorganizmaların cilde girişini kolaylaştıran çatlaklar oluşur ve sonuçta uzun süre ilaç tedavileri gerektiren ayak enfeksiyonları ortaya çıkar (Iraj, 2013). Amin ve ark. diyabetik ayağa sahip 100 hasta ile yaptıkları çalışmalarında hastaların \%50'sinin travma öyküsü olduğunu saptamış ve travma öyküsünün diyabetik ayak ülserleri için önemli bir risk faktörü olduğunu belirtmişlerdir (Amin, 2015).

\section{Sonuç}

Sonuç olarak, ayak ülseri riski olan diyabetik hastaların belirlenmesi, risk sınıflandırmasının yapılması, hastanede kalış süresini ve sağlık maliyetlerini azaltma, morbidite ve mortalite oranlarını düşürme açısından önemlidir. Bu nedenle diyabetik ayak ülserinin ortaya çıkmasına ve ortaya çıkan yaraların iyileşmesinin gecikmesine neden olan risk faktörlerini belirlemek, hastaların bu risk faktörlerinden korunmasını sağlamak; etkin tedavi yöntemlerinin ve önleyici bakım girişimlerinin belirlenmesine yardım edecektir.

\section{Kaynaklar}

1. Abbott, C. A., Carrington, A. L., Ashe, H., Bath, S., Every, L. C., Griffiths, J., ... Boulton, A. J. (2002). The North-West Diabetes Foot Care Study: incidence of, and risk factors for, new diabetic foot ulceration in a community-based patient cohort. Diabetic Medicine: A Journal of The British Diabetic Association, 19(5), 377-384. https://doi.org/10.1046/j.14645491.2002.00698.x

2. Ahmad J. (2016). The diabetic foot. Diabetes \& Metabolic Syndrome, 10(1), 48-60. https:// doi.org/10.1016/j.dsx.2015.04.00

3. Ahmad, W., Khan, I. A., Ghaffar, S., Al-Swailmi, F. K., Khan, I. (2013). Risk factors for diabetic foot ulcer. Journal of Ayub Medical College Abbottabad, 25(1-2), 16-18.

4. Akçay, S., Satoğlu, I.S., Harman, E., Kurtulmuş, A., Kazımoğlu, C. (2012). Diyabetik ayak ülserli hastalarda amputasyon oranı ve eşlik eden komorbiditelerin retrospektif analizi. Medicine Science, 1(4), 331-340.

5. Al-Rubeaan, K., Al Derwish, M., Ouizi, S., Youssef, A. M., Subhani, S. N., Ibrahim, H. M., Alamri, B. N. (2015). Diabetic foot complications and their risk factors from a large retrospective cohort study. PloS one, 10(5), e0124446. https://doi.org/10.1371/journal.pone.0124446

6. American Diabetes Association. (2020). Introduction: Standards of Medical Care in Diabetes-2020. Diabetes Care, 43(Suppl 1), S1-S2. doi:10.2337/dc20-Sint. PMID: 31862741. http://www.ncbi.nlm.nih.gov/pubmed/31862741 (Erişim Tarihi: 01.05.2021)

7. Amin A., Uddin, M.T., Iqbal, Z., Kashif, M., Ahmed, Z.S., Gulsharif. (2015). Frequency \& the risk factors of diabetic foot. Ophthalmology Update, 13(4), 315-317.

8. Amin, N., Doupis, J. (2016). Diabetic foot disease: From the evaluation of the "foot at risk" to the novel diabetic ulcer treatment modalities. World Journal of Diabetes, 7(7), 153-164. https://doi.org/10.4239/wjd.v7.i7.153

9. Amoah, V.M.K., Anokye, R., Acheampong, E., Dadson, H.R., Osei, M., Nadutey, A. (2018). The experiences of people with diabetesrelated lower limb amputation at the Komfo Anok- 
ye Teaching Hospital (KATH) in Ghana, BMC Res Notes, 11(1), 66. https://doi.org/10.1186/ s13104-018-3176-1

10. Ayanoğlu, S. (2015). Diyabetik ayak hastalığına güncel yaklaşımlar. Okmeydanı Tıp Dergisi, 31(Ek sayı), 63-71.

11. Biberoğlu, K. Illiçin, G. (2003). Iç Hastalıkları: Diyabetin Komplikasyonları. 2. Baskı. İstanbul: Güneş Tıp Kitabevi.

12. Börkü Uysal, B. (2019). Diyabetin makrovasküler komplilasyonları. Çarlıoğlu, A., Akbaş, E.M., Kartal Baykan, E. (Ed.), Diyabete Multidisipliner Yaklaşım. Ankara:Akdemisyen Kitabevi.

13. Coşansu, G. (2015). Diyabet: Küresel bir salgın hastalık. Okmeydanı Tıp Dergisi, 31(Ek sayı), $1-6$.

14. Demir, T., Akıncı, B., Yeşil, S. (2007). Diyabetik ayak ülserlerinin tanı ve tedavisi. Dokuz Eylü Üniversitesi Tıp Fakültesi Dergisi, 21(1), 63-70.

15. Demir, Y., Demir, S., Gökçe, Ç. (2004). Diyabetik Ayak: fizyopatolojisi, tanısı ve rekonstrüksiyon öncesi tedavisinde güncel yaklaşımlar. Kocatepe Tıp Dergisi, 5(3), 1-12. doi: 10.1371/ journal.pone.0124446.

16. Ekim, M., Ekim H. (2016). Diyabetik ayak ülserlerinde etiyoloji ve tedavi. Van Tıp Dergisi, 23(2), 235-241.

17. Fiçioğlu, C., Aydın, A., Hakan, M., Kızıltan, M. (1994). Peripheral neuropathy in children with insülin dependent diabetes mellitus. Turk J Pediatri, 36(2), 97-104.

18. Güner, A. (2005). Diyabetik hastaların diyabetik ayak ile ilgili bilgi ve tutumlarının irdelenmesi ve HBA1C'nin diabetik ayak ile ilişkisi, Taksim Eğitim ve Araştırma Hastanesi, Uzmanlık tezi, İstanbul.

19. Hokkam, E.N. (2009). Assesment of risk factors in diabetic foot ulceration and their impact on the outcome of the disease. Primary care diabetes, 3(4), 219-224.

20. Ibrahım, A., Jude, E., Langton, K., Jesus, F.R.M., Harkless, L.B., Gawısh, H..... Cho, N.H. (2017) IDF Clinical Practice Recommendations on the Diabetic Foot - 2017. International Diabetes Federation

21. IDF - International Diabetes Federation. Diabetes Atlas. 9th Edition, 2019. https://www diabetesatlas.org/data/en/country/203/tr.html (Erişim Tarihi: 01.05.2021)

22. International Diabetes Federation and the International Working Group on the Diabetic Foot. Put Feet First Prevent Amputations, Diabetes and Foot Care, Time to Act 2005. https://d-foot.org/images/pdf/put-feet-first.pdf (Erişim Tarihi: 01.05.2021)

23. Iraj, B., Khorvash, F., Ebneshahidi, A., Askari, G. (2013). Prevention of diabetic foot ulcer. In ternational Journal of Preventive Medicine, 4(3), 373-376.

24. Jan, A.W., Khan, H., Ahmad, I., Khan, M. (2016). Diabetic Foot Ulcer; Risk factors stratification in patients. a study of 150 patients. The Professional Medical Journal, 23(6), 693-698.

25. Kalpakçı, P., Sezer, R.E., Yılmaz, S., Öztürk, H., Erturhan, S. (2014). Cumhuriyet Üniversites Hastanesi'nde 2007-2012 döneminde diyabetik ayağa bağlı operasyon olan hastaların özellikleri ile yaş ve cinsiyetin diyabetik ayak operasyonlarını tahmin ettirici etkisi. Türkiye Aile Hekimliği Dergisi, 18(2), 54-57.

26. Kästenbauer, T., \& Irsigler, K. (2003). Das diabetische Fusssyndrom [Diabetic foot syndrome]. Wiener medizinische Wochenschrift (1946), 153(21-22), 474-477. https://doi. org/10.1007/s10354-003-0038-8

27. Korkmaz, M., Şener, N., Bayram, E., Yılmaz, M., Çetinus, M.E. (2015). Diyabetik ayak yaraları ve klinik deneyimimiz. Bakırköy Tıp Dergisi, 11(2), 60-65.

28. Lauterbach, S., Kostev, K., \& Kohlmann, T. (2010). Prevalence of diabetic foot syndrome and its risk factors in the UK. Journal of wound care, 19(8), 333-337. https://doi.org/10.12968/ jowc.2010.19.8.77711

29. Moss, S.E., Klein, R., Klein, B.E., Wong, T.Y. (2003). Retinal vascular changes and 20-year in- cidence of lower extremity amputations in a cohort with diabetes. Archives of Internal Medicine, 163(20), 2505-2510. https://doi.org/10.1001/archinte.163.20.2505

30. Naicker A.S., Ohnmar H., Choon S.K. (2009). A study of risk factors asso-ciated with diabetic foot, knowledge and practice of foot care among diabetic patients. Int Med J, 16(3), 189-193.

31. Önmez, A. (2017). Diabetes Mellitus'ta mikrovasküler komplikasyonların yönetimi. Düzce Üniversitesi Sağlık Bilimleri Enstitüsü Dergisi, 7 (2), 117-119.

32. Özkara, A., Aktürk, M., Delibaşı, T., Karaahmetoğlu, S. (2002). Diyabetik ayaklı 84 hastada risk faktörlerinin incelenmesi. Türkiye Tıp Dergisi, 9(3), 105-105.

33. Özşenel, E.B., Gürler, M.Y., Karatemiz, G., Sünbül, M., Çiloğlu, M., Sakçı, E. (2014). Diyabetik mikrovasküler komplikasyonu olan ve olmayan hastaların MPV ve sensitif CRP düzeylerinin karşılaştırılması. Haseki Tıp Bülteni, 57-61.

34. Pop-Busui, R., Boulton, A. J., Feldman, E. L., Bril, V., Freeman, R., Malik, R. A., ... Ziegler, D. (2017). Diabetic Neuropathy: A position statement by the American Diabetes Association. Diabetes Care, 40(1), 136-154. https://doi.org/10.2337/dc16-2042

35. Prompers, L., Schaper, N., Apelqvist, J., Edmonds, M., Jude, E., Mauricio, D. ... Huijberts M. (2008). Prediction of outcome in individuals with diabetic foot ulcers: focus on the differences between individuals with and without peripheral arterial disease. The EURODIALE Study. Diabetologia, 51(5), 747-55.

36. Rajyalakshmi, Y. (2017). Evaluation and management of diabetic foot according to Wagner's Classification, Journal of Dental and Medical Sciences, 16(12), 25-33.

37. Sağlık Bakanlığı Türkiye Diyabet Programı 2015-2020. https://extranet.who.int/ncdccs/ Data/TUR_D1_T\%C3\%BCrkiye\%20Diyabet\%20Program\%C4\%B1\%202015-2020.pdf (Erişim Tarihi: 01.05.2021)

38. Said G. (2007). Diabetic neuropathy - a review. Nature Clinical Practice, 3(6), 331-340

39. Satman, İ., İmamoğlu, Ş., Yılmaz, C., Ayvaz, G., Çömlekçi, A. (2012). Türkiye'de ve Dünya'da Diyabet. Türkiye Endokrinoloji ve Metabolizma Derneği (TEMD) Diabetes Mellitus Çalışma ve Eğitim Grubu Raporu, 3-50.

40. Schaper, N.C. (2012). Lessons from Eurodiale. Diabetes/Metabolism Research And Reviews, 28 Suppl 1, 21-26. https://doi.org/10.1002/dmrr.2266

41. Sözen, E., Kızılcı, S. (2012). Tip 2 Diyabetlilerde ayak bakım davranışlarının incelenmesi ve karşılaştırılması. Ege Üniversitesi Hemşirelik Fakültesi Dergisi, 28(2), 41-53.

42. Sunny, S., Pradeep, S., Sunny, A.A., Parthasarathy, R., Rajeshkumar, S. (2019). Patient counseling, risk factors and comorbidity assessment in diabetic foot ulcer. Journal of Research in Pharmacy, 23(2), 298-303.

43. Toygar, İ., Hançerlioğlu, S., Yıldııım Şimşir, I., Çetinkalp, Ş. (2020). Diyabetik ayak hastalarının yaşam kalitesi ve etkileyen faktörler. Ege Tıp Dergisi, 59(4), 272-279.

44. Türkiye Diyabet Vakfı. Diabetes Mellitus Tanı, Sınıflama ve İzlem İlkeleri. TÜRKDiAB Diyabet Tanı ve Tedavi Rehberi 2020. İstanbul:Pasifik, s:16

45. Türkiye Endokrinoloji ve Metabolizma Derneği (TEMD). Diabetes Mellitus ve Komplikasyonlarının Tanı, Tedavi ve İzlem Kılavuzu 2020. Ankara:TEMD Yayınları. https://temd.org. tr/admin/uploads/tbl_kilavuz/20200625154506-2020tbl_kilavuz86bf012d90.pdf (Erişim Tarihi: 01.05.2021)

46. Uludağ, M.O. (2010). Diyabete bağlı ikincil hastalıklar (komplikasyonlar). Diyabet ve Obezite Dergisi, 23-24, 39-44.

47. World Health Organization, "Global Report on Diabetes". (2016). https://apps.who.int/iris/ bitstream/handle/10665/204871/9789241565257_eng.pdf;jsessionid=8BAFBCCE363AAA5178B054877E3C026A?sequence $=1$ (Erişim Tarihi: 01.05.2021)

48. World Health Organization. Noncommunicable Diseases Progress Monitor 2017. https:// www.who.int/publications/i/item/WHO-NMH-NVI-17.9 (Erişim Tarihi: 01.05.2021) 